\title{
Variation in the steroidogenic responsiveness of isolated rat Leydig cells
}

\author{
R. M. Sharpe and I. Cooper \\ M.R.C. Reproductive Biology Unit, Centre for Reproductive Biology, 37 Chalmers Street, \\ Edinburgh EH3 9EW, U.K.
}

\begin{abstract}
Summary. Isolated Leydig cells were prepared from adult rat testes by (1) mechanical dissection, (2) collagenase dispersion or (3) mechanical dissection followed by collagenase dispersion, and their functional characteristics were assessed. Compared with Methods 2 and 3, mechanical isolation alone resulted in the purest preparation of Leydig cells but the lowest yield. Leydig cells isolated by any of the 3 methods had similar numbers of LH- and LH-RH receptors, but cells isolated by Methods 1 and 3 showed poor testosterone responsiveness compared to cells isolated by Method 2. This reduced response was evident following stimulation with hCG, dibutyryl cyclic AMP or an LH-RH agonist, and could not be accounted for simply on the grounds of diminished cell viability. It is concluded that Leydig cells in the rat testis are particularly sensitive to mechanical intrusion, and this is an important factor to bear in mind when preparing Leydig cells or when comparing results between laboratories.
\end{abstract}

\section{Introduction}

Isolated Leydig cells from the rat testis are used extensively in endocrine research for studies on the regulation of Leydig cell function, for investigation of the control of steroidogenesis and in the in-vitro bioassay of luteinizing hormone (LH)-like activity. Essentially, three methods have been used to obtain Leydig cell-enriched preparations of testicular interstitial cells, mechanical isolation (e.g. Christensen \& Mason, 1965), enzymic dispersion (e.g. Moyle \& Ramachandran, 1973; Dufau, Mendelson \& Catt, 1974), or a combination of these two methods (e.g. Shaw, Georgopoulos \& Payne, 1979; Sharpe \& Fraser, 1980a). The relative merits of these methods have not been compared directly, but it is generally accepted that the yield of Leydig cells is much higher using the enzymic methods whilst mechanical isolation alone results in a much 'purer' preparation of Leydig cells. Variation in the characteristics or activity of cells as a result of the method of preparation could obviously have widespread repercussions, particularly when comparing results from different laboratories. We have therefore compared the functional characteristics of Leydig cells prepared using the above 3 methods.

\section{Materials and Methods}

\section{Animals}

Adult male rats from our own colonies of Liverpool Hooded or Sprague-Dawley rats were used to provide cells and were kept under conventional conditions. 


\section{Isolation of Leydig cells}

Groups of 8 rats were killed with $\mathrm{CO}_{2}$, their testes removed and decapsulated carefully to avoid damage to the testicular tissue. One testis per rat was allocated to a pool to be mechanically-treated, whilst the contralateral testis was allocated alternately either to a pool to be dispersed enzymically with collagenase or to a pool to be mechanically teased apart and then dispersed with collagenase.

The mechanical isolation of cells was achieved as follows. Testes were immersed in Krebs-Ringer bicarbonate (KRB) solution (for details of composition, see Sharpe \& Fraser, $1980 \mathrm{c}$ ) in a Petri dish and then gently teased using fine forceps; dissection was extremely limited and care was taken to minimize damage to the seminiferous tubules. Collagenase dispersion was effected essentially as described previously (Sharpe \& McNeilly, 1980). Groups of 4 decapsulated testes were incubated in $50 \mathrm{ml}$ glass conical flasks together with $6 \mathrm{ml}$ of a solution of collagenase (Type 1, Sigma; $0.25 \mathrm{mg} / \mathrm{ml}$ ) in KRB for $15 \mathrm{~min}$ at $34^{\circ} \mathrm{C}$ in a shaking water bath (100 cycles $/ \mathrm{min}$ ). The third method of preparing cells combined these 2 procedures; groups of 4 testes were teased gently apart in $6 \mathrm{ml}$ collagenase solution and this material then incubated for 15 min as described for collagenase dispersion. None of these methods caused other than minor disruption or breakage of the seminiferous tubules.

Subsequent separation of isolated cells from the remaining testicular tissue was effected for all groups by diluting to $50 \mathrm{ml}$ with KRB in a measuring cylinder and then allowing the mass of seminiferous tubules to settle over the next $3 \mathrm{~min}$. The supernatant was then aspirated and centrifuged gently for $5 \mathrm{~min}$ at $250 \mathrm{~g}$ at $4^{\circ} \mathrm{C}$, and the precipitated cells were resuspended immediately in KRB containing glucose $(2 \mathrm{mg} / \mathrm{ml})$ and bovine serum albumin (BSA; fraction V, Sigma; 0.2\%) (= KRBG).

The nucleated cell concentration was determined by counting aliquots of cells in a haemocytometer, and the percentage of Leydig cells was assessed on the basis of positive staining for $3 \beta$-hydroxysteroid dehydrogenase ( $3 \beta$-HSD), using a modification of the method of Levy, Dean \& Rubin (1959). To a $0.2 \mathrm{ml}$ aliquot of cells, the following were added in sequence: $0.1 \mathrm{ml} \beta$-nicotinamide adenine dinucleotide (Sigma, $6 \mathrm{mg} / \mathrm{ml}$ ), $0.1 \mathrm{ml}$ of a saturated solution of $5 \beta$-androstan-3 $\beta$-ol-17one (Sigma) and $0.2 \mathrm{ml}$ nitro-blue tetrazolium (Sigma, $1 \mathrm{mg} / \mathrm{ml}$ ). Cells were then incubated for $30 \mathrm{~min}$ at $34^{\circ} \mathrm{C}$ and the percentage of positively staining nucleated cells was determined in a haemocytometer.

\section{Assessment of testosterone responsiveness}

Aliquots of cells from the various treatment groups were dispensed into $83 \times 13 \mathrm{~mm}$ polystyrene tubes together with known concentrations of hCG (Chorulon, Intervet), dibutyryl cyclic AMP (Sigma) or an LH-RH agonist ((D-Ser-t-bu ${ }^{6}$,des-Gly- $\mathrm{NH}_{2}{ }^{10}$ ) LHRH ethylamide) (Hoechst, A. G., West Germany). The final incubation volume was $0.65 \mathrm{ml}$, and all materials were dissolved in KRBG before addition. The tubes were then incubated for $4 \mathrm{~h}$ at $34^{\circ} \mathrm{C}$ in a shaking water bath under an atmosphere of $95 \% \mathrm{O}_{2}: 5 \% \mathrm{CO}_{2}$. At the end of incubation, tubes were centrifuged for $10 \mathrm{~min}$ at $1000 \mathrm{~g}$ and the supernatant decanted and stored at $-20^{\circ} \mathrm{C}$. The number of $3 \beta$-HSD positive (Leydig) cells added per tube varied between experiments from 0.8 to $1.5 \times 10^{6}$, but within any single experiment, approximately equal numbers of cells $( \pm 20 \%)$ were used for each of the preparation methods.

Testosterone levels in the incubation medium were assayed after appropriate dilution as described elsewhere (Sharpe, Fraser \& Sandow, 1979; Sharpe \& McNeilly, 1980) using radioimmunoassay (Corker \& Davidson, 1978), and expressed as ng/1063 $3 \beta$-HSD positive cells.

\section{Assessment of cell viability}

Cell viability was assessed by the ability of cells to exclude trypan blue. Equal volumes of the cell suspension and a $\mathbf{0 . 0 5 \%}$ solution of trypan blue (Sigma) were incubated together for 10 
min at $21^{\circ} \mathrm{C}$, and the numbers of stained and unstained nucleated cells were determined with a haemocytometer. This procedure was performed in duplicate on freshly isolated cells (i.e. before incubation) and on cells which had been incubated in the absence of hormonal stimulation for 4 $h$ at $34^{\circ} \mathrm{C}$ as described above.

\section{Binding of ${ }^{125}$ I-labelled $h C G$}

This was assessed essentially as described elsewhere (Sharpe \& McNeilly, 1980). Aliquots of approximately $0.5 \times 10^{6}$ Leydig cells were incubated in $63 \times 11 \mathrm{~mm}$ tubes for $2 \mathrm{~h}$ at $34^{\circ} \mathrm{C}$ in the presence of a saturating concentration $(100 \mathrm{ng} / \mathrm{ml})$ of ${ }^{125}$ I-labelled hCG (hCG CR 119; $11600 \mathrm{i} . \mathrm{u} . / \mathrm{mg}$ ). The labelled hormone was prepared using lactoperoxidase (Miyachi, Vaitukaitis, Nieschlag \& Lipsett, 1972) and had a specific activity of $45 \mu \mathrm{Ci} / \mu \mathrm{g}$. Assessement of non-specific binding and the separation procedure were as described elsewhere (Sharpe \& McNeilly, 1980).

\section{Binding of ${ }^{125}$ I-labelled LH-RH agonist}

This was assessed essentially as described previously (Sharpe \& Fraser, 1980a, b). Aliquots of approximately $1.5 \times 10^{6}$ Leydig cells were incubated in $63 \times 11 \mathrm{~mm}$ tubes for $45 \mathrm{~min}$ at $21^{\circ} \mathrm{C}$ in the presence of a saturating concentration $(2.5 \mathrm{nM})$ of ${ }^{125}$ I-labelled LH-RH agonist ((D-Ser-t-bu ${ }^{6}$,des-Gly- $\left.\mathrm{NH}_{2}{ }^{10}\right)$ LHRH ethylamide) which was prepared using lactoperoxidase as described previously (Sharpe \& Fraser, 1980a) and had a specific activity of $1100 \mu \mathrm{Ci} / \mu \mathrm{g}$. Assessment of non-specific binding and the separation procedure were as described previously (Sharpe \& Fraser, 1980a, b).

\section{Results}

\section{Yield and viability of cells}

In terms of the percentage of nucleated cells which stained for $3 \beta$-HSD (i.e. Leydig cell purity), the mechanical isolation procedure was considerably superior to the other two methods, although the total yield of $3 \beta$-HSD positive cells showed the reverse picture with more than a 5 -fold increase using collagenase dispersion alone and more than an 8-fold increase when collagenase treatment followed mechanical teasing (Table 1). With all 3 separation methods, more than $90 \%$ of the freshly isolated cells appeared viable. However, viability was reduced in all

Table 1. Effect of the preparation method on the yield, purity, viability and testosterone responsiveness of rat Leydig cells

\begin{tabular}{|c|c|c|c|c|c|}
\hline \multirow[b]{2}{*}{$\begin{array}{l}\text { Preparation } \\
\text { method }\end{array}$} & \multirow[b]{2}{*}{$\begin{array}{c}\% 3 \beta \text {-HSD } \\
\text { positive cells }\end{array}$} & \multirow{2}{*}{ 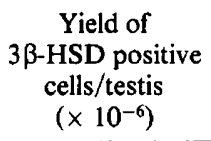 } & \multicolumn{2}{|c|}{$\%$ viable cells } & \multirow{2}{*}{$\begin{array}{l}\text { Testosterone } \\
\text { responsiveness } \\
\text { in vitro† }\end{array}$} \\
\hline & & & $\begin{array}{c}\text { Before } \\
\text { incubation }\end{array}$ & $\begin{array}{c}\text { After } 4 \mathrm{~h} \\
\text { incubation }\end{array}$ & \\
\hline Mechanical & $\begin{array}{c}76 \pm 9^{* * *} \\
(6)\end{array}$ & $4 \cdot 7 \pm 2 \cdot 0^{* *}$ & $91 \pm 4$ & $47 \pm 8^{*}$ & $\begin{array}{c}2.0 \pm 0.9 * * \\
(5)\end{array}$ \\
\hline Collagenase & $49 \pm 4$ & $27 \cdot 8 \pm 4.4$ & $91 \pm 4$ & $75 \pm 2$ & $9 \cdot 5 \pm 2.7$ \\
\hline $\begin{array}{r}\text { Mechanical }+ \\
\text { Collagenase }\end{array}$ & $47 \pm 1$ & $40 \cdot 6 \pm 4 \cdot 0^{*}$ & $\begin{array}{l}94 \\
\text { (1) }\end{array}$ & $\begin{array}{l}70 \\
\text { (1) }\end{array}$ & $3 \cdot 0 \pm 0.2^{*}$ \\
\hline
\end{tabular}

Results are the mean \pm s.d. and the number of experiments is shown in parentheses.

* $P<0.01,{ }^{* *} P<0.001$ compared with value for collagenase isolated cells (Student's $t$ test).

$\uparrow$ Calculated as the maximal secretion of testosterone (i.e. in the presence of excess hCG or dibutyryl cyclic AMP) divided by the basal secretion of testosterone (i.e. secretion in the absence of hormones). 
Table 2. Receptor levels in relation to testosterone responsiveness of Leydig cells prepared mechanically or by collagenase dispersion

\begin{tabular}{lcc}
\hline & \multicolumn{2}{c}{ Leydig cell isolation method } \\
\cline { 2 - 3 } & Mechanical & Collagenase \\
\hline In-vitro testosterone production (ng) & & \\
$\quad$ Basal & $2.9 \pm 0.2$ & $2 \cdot 7 \pm 0.2$ \\
$\quad$ hCG-stimulated $\dagger$ & $3.8 \pm 0.3$ & $23.8 \pm 0.9^{*}$ \\
$\quad$ LHRH agonist-stimulated $\dagger$ & $3 \cdot 5 \pm 0.2$ & $5.4 \pm 0.3^{*}$ \\
$\begin{array}{l}\text { LH-receptor numbers } \\
\quad \text { (ng }{ }^{125} \text { I-labelled hCG bound) }\end{array}$ & $1.4 \pm 0.1$ & $1.5 \pm 0.1$ \\
$\begin{array}{l}\text { LHRH-receptor numbers } \\
\text { (pg }{ }^{125} \text { I-labelled LHRH agonist bound) }\end{array}$ & $4.6 \pm 0.3$ & $4.3 \pm 0.1$ \\
\hline
\end{tabular}

Results are expressed per $10^{6} 3 \beta$-HSD positive cells and are the mean \pm s.d. for triplicate or quadruplicate incubations. The results shown are from a single experiment but are representative of at least 2 experiments.

$* P<0.001$, compared with respective value for mechanically isolated cells.

† Maximally stimulating concentrations.

groups following $4 \mathrm{~h}$ incubation and this reduction was significantly greater in mechanicallythan in collagenase-isolated cells (Table 1), although this measure of viability did not distinguish between Leydig and non-Leydig cells.

\section{Testosterone responsiveness}

There was no consistent or significant difference in basal testosterone secretion by Leydig cells isolated by any of the three methods, but there were large differences in their capacity to

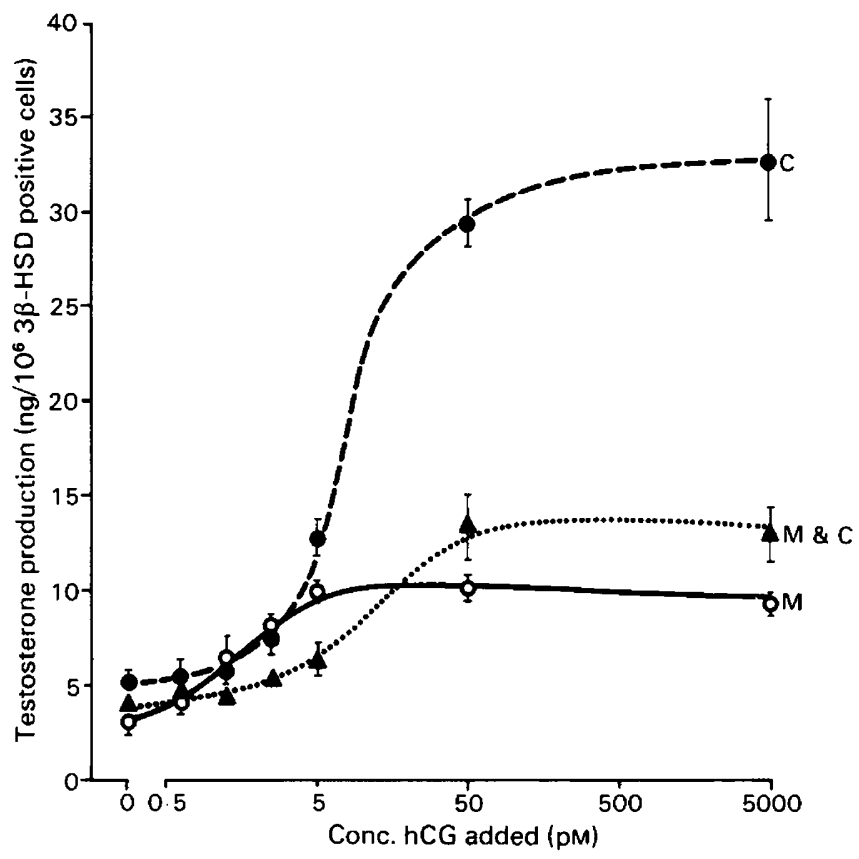

Text-fig. 1. Dose-response relationship between the concentration of added hCG and testosterone production by adult rat Leydig cells isolated mechanically (M), by using collagenase (C) or by a combination of these two methods ( $M$ and $C$ ). Results are the mean \pm s.d. for triplicate incubations and are representative of several experiments. 


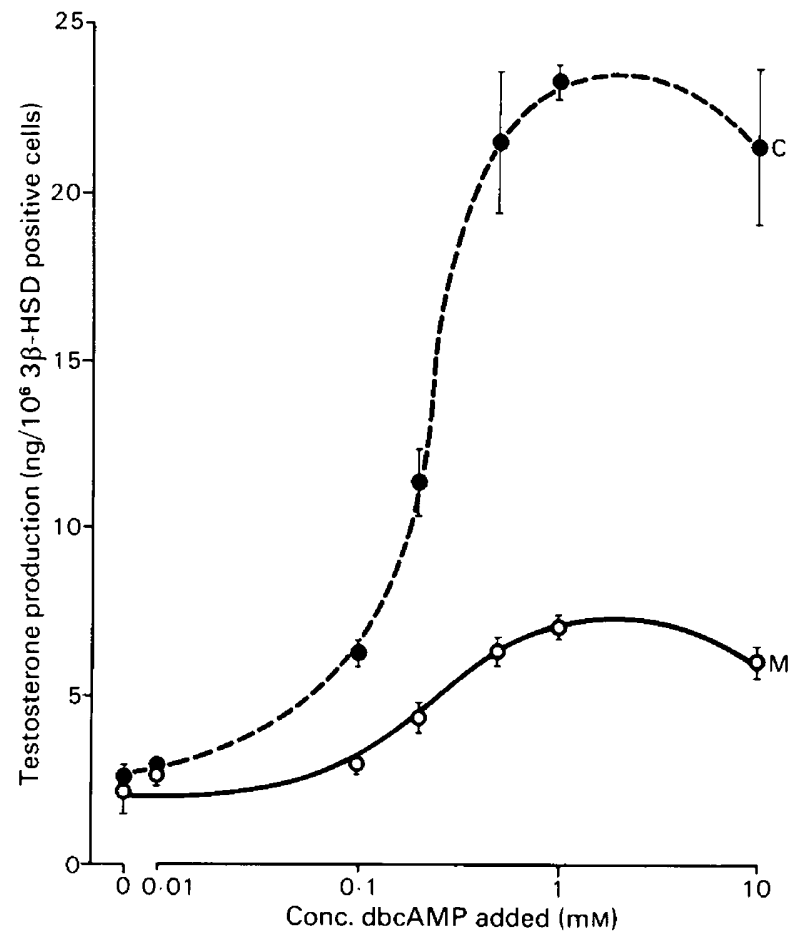

Text-fig. 2. Dose-response relationship between the concentration of added dibutyryl cyclic AMP and testosterone production by adult rat Leydig cells isolated mechanically $(M)$ or by using collagenase $(\mathrm{C})$. Results are the mean \pm s.d. for triplicate incubations and are representative of 2 experiments.

respond to hCG-stimulation (Text-fig. 1; Tables 1 and 2). Cells in all 3 groups responded to hCG by significantly $(P<0.001)$ increasing testosterone output, but the magnitude of this increase was, on average, only 2 -fold in mechanically-isolated cells compared with over 9-fold in collagenase-isolated cells. Combination of these two isolation procedures resulted in cells which were only marginally more responsive than cells isolated using the mechanical method alone, despite the enormous increase in the yield of Leydig cells (Table 1). Similarly, testosterone secretion in response to dibutyryl cyclic AMP showed the same order of difference between mechanically- and collagenase-isolated Leydig cells (Text-fig. 2), and stimulation of testosterone secretion by LHRH agonist (for details see Sharpe \& Cooper, 1982) was significantly greater in collagenase- than in mechanically-isolated Leydig cells (Table 2).

\section{LH- and LHRH-receptor numbers}

There was no significant difference in the number of $\mathrm{LH}$ (hCG)- or LH-RH receptors between Leydig cells isolated mechanically or using collagenase (Table 2). Similarly, in a separate experiment, no differences in receptor numbers were observed between Leydig cells isolated by collagenase alone or by the combined mechanical and collagenase method (data not shown).

\section{Discussion}

These results demonstrate that the functional characteristics of isolated rat Leydig cells vary according to the method of preparation. The mechanical dissection procedure, which involves 
gentle teasing apart of the testis with fine forceps, results in cells which show a poor testosterone response to stimulation by a number of factors in vitro. This is despite the presence on these cells of similar numbers of hormone receptors to those on cells isolated by collagenase and which show a strong testosterone response to stimulation. An obvious explanation for this difference would be that the cells isolated mechanically were more 'damaged' than those isolated using the less invasive technique of collagenase digestion. Although no such difference was evident from trypan blue exclusion studies on freshly isolated cells, after $4 \mathrm{~h}$ incubation there was evidence of increased damage to mechanically-isolated cells. However, even if it were assumed that all of the damaged cells at $4 \mathrm{~h}$ in the latter group were Leydig cells whilst all damaged cells in the collagenase treatment group were non-Leydig cells, the difference in responsiveness of cells in these 2 groups could still only be partly accounted for. Further support for this interpretation is provided by the observation that cells isolated by a combination of mechanical teasing and collagenase digestion showed similar viability to cells isolated by collagenase alone but were still only one third as responsive. This result confirms the findings of Dufau, Catt \& Tsuruhara (1971) who demonstrated that intact decapsulated rat testes were able to respond to stimulation with hCG or dibutyryl cyclic AMP, but testes which had been mechanically teased apart showed little if any response. These results together with the present findings therefore strongly suggest that any intrusive mechanical disruption of the rat testes, no matter how carefully it is done, will result in functional damage to the Leydig cells isolated by this procedure and to the Leydig cells remaining in the testis. These results also indicate that extreme care should be taken to minimize mechanical damage when manipulating and decapsulating rat testes for collagenase dispersion or other studies. In contrast to the rat, Leydig cells isolated by vigorous mechanical dispersion of mouse testes retain full steroidogenic responsiveness to LH (Schumacher, Schafer, Holstein \& Hilz, 1978), but the reason for this species difference is unknown.

Other than some change in viability, the precise cause of the impaired responsiveness of mechanically prepared Leydig cells is unclear, although two possible explanations can be ruled out. First, it does not result from an 'inhibitor' produced by mechanically isolated cells, because co-incubation of such cells together with collagenase-isolated cells failed to alter the responsiveness of the latter cells (unpublished data). Second, the possibility that mechanical isolation selects out a sub-population of 'low-responsive' Leydig cells from the heterogeneous Leydig cell population (Payne, Downing \& Wong, 1980; Cook, Magee-Brown, Golding \& Dix, 1981 ) is untenable in view of the results of Dufau et al. (1971) with whole testes, and the present findings on the poor responsiveness of the large numbers of Leydig cells isolated by the combined mechanical and collagenase method.

The yields of Leydig cells reported in the present paper (Table 1) are high in relation to the number of Leydig cells reported using histological and morphometric techniques. Mori \& Christensen (1980) concluded that the adult rat testis contained approximately $34 \times 10^{6}$ Leydig cells, whilst the presently reported mean yield of Leydig cells following collagenase digestion and the combined mechanical and collagenase isolation procedure were 28 and $41 \times 10^{6}$ per testis, respectively. This raises the possibility that we identified some non-Leydig cells as staining positively for $3 \beta-\mathrm{HSD}$, and the high proportion of nucleated cells which were scored as staining positively for this enzyme in our experiments (Table 1) could be taken as evidence in favour of this interpretation. Certainly, the normal extreme inter-cell variation in the degree of staining for 3ß-HSD (see Purvis, Clausen \& Hansson, 1978) creates difficulties in identification, but in our hands the present findings are repeatable; for example, our last 21 preparations of Leydig cells by collagenase digestion alone have resulted in a mean ( \pm s.d.) yield of $19.8 \pm 6.4 \times 10^{6}$ $3 \beta$-HSD positive cells per testis with a Leydig cell purity of $46 \pm 7 \%$. Moreover, when we have tested cell preparations from rats in which the testicular $3 \beta$-HSD activity has been increased experimentally (by active immunization against testosterone), thereby enhancing the degree of staining and the ease of identification, over $40 \%$ of nucleated cells still stained positively for $3 \beta$-HSD (R. Sharpe, H. Fraser \& I. Cooper, unpublished data). 
We are grateful to Dr S. Dombey and Dr J. Sandow (Hoechst, A. G.) for LH-RH agonist and to the NIAMDD, U.S.A. for purified hCG.

\section{References}

Christensen, A.K. \& Mason, N.R. (1965) Comparative ability of seminiferous tubules and interstitial tissue of rat testes to synthesize androgens from progesterone-4- ${ }^{14} \mathrm{C}$ in vitro. Endocrinology 76, 646-656.

Cook, B.A., Magee-Brown, R., Golding, M. \& Dix, C.J. (1981) The heterogeneity of Leydig cells from mouse and rat testes-evidence for a Leydig cell cycle? Int. J. Androl. 4, 355-366.

Corker, C.S. \& Davidson, D.W. (1978) Radioimmunoassay of testosterone in various biological fluids without chromatography. J. Steroid Biochem. 9, 373374.

Dufau, M.L., Catt, K.J. \& Tsuruhara, T. (1971) Gonadotrophin stimulation of testosterone production by the rat testis in vitro. Biochim. Biophys. Acta 252, 574-579.

Dufau, M.L., Mendelson, C.R. \& Catt, K.J. (1974) A highly sensitive in vitro bioassay for luteinizing hormone and chorionic gonadotropin: testosterone production by dispersed Leydig cells. J. clin. Endocr. Metab. 39, 610-613.

Levy, H., Dean, H.W. \& Rubin, B.L. (1959) Visualization of steroid-3 $\beta$-ol-dehydrogenase activity in tissues of intact and hypophysectomized rats. Endocrinology 65, 932-943.

Miyachi, Y., Vaitukaitis, J.L., Nieschlag, E. \& Lipsett, M.B. (1972) Enzymic radioiodination of gonadotropins. J. clin. Endocr. Metab. 34, 23-28.

Mori, H. \& Christensen, A.K. (1980) Morphometric analysis of Leydig cells in the normal rat testis $J$. Cell Biol. 84, 340-354.

Moyle, W.R. \& Ramachandran, J. (1973) Effect of LH on steroidogenesis and cyclic AMP accumulation in rat Leydig cell preparations and mouse tumor Leydig cells. Endocrinology 93, 127-134.

Payne, A.H., Downing, J.R. \& Wong, K.L. (1980) Luteinizing hormone receptors and testosterone synthesis in two distinct populations of Leydig cells. Endocrinology 106, 1424-1429.
Purvis, K., Clausen, O.P.F. \& Hansson, V. (1978) Functional characteristics of rat Leydig cells. Annls Biol. anim. Biochim. Biophys. 18, 595-605.

Schumacher, M., Schafer, G., Holstein, A.F. \& Hilz, H. (1978) Rapid isolation of mouse Leydig cells by centrifugation in Percol density gradients with complete retention of morphological and biochemical integrity. FEBS Letters 91, 333-338.

Sharpe, R.M. \& Cooper, I. (1982) Stimulatory effect of LHRH and its agonists on Leydig cell steroidogenesis in vitro. Molec. cell. Endocr. (in press).

Sharpe, R.M. \& Fraser, H.M. (1980a) Leydig cell receptors for luteinizing hormone releasing hormone and its agonists, and their modulation by administration or deprivation of the releasing hormone. Biochem. Biophys. Res. Commun. 95, 256-262.

Sharpe, R.M. \& Fraser, H.M. (1980b) hCG stimulation of testicular LHRH-like activity. Nature, Lond. 287, 642-643.

Sharpe, R.M. \& Fraser, H.M. (1980c) Inhibition of maturational changes in Leydig cell function by tratment of rats with an agonist of Lh-RH. $J$. Reprod. Fert. 60, 359-368.

Sharpe, R.M. \& McNeilly, A.S. (1980) Differences between dispersed Leydig cells and intact testes in their sensitivity to gonadotrophin-stimulation in vitro after alteration of LH-receptor numbers. Molec. cell. Endocr. 18, 75-86.

Sharpe, R.M., Fraser, H.M. \& Sandow, J. (1979) Effect of treatment with an agonist of luteinizing hormone releasing hormone on early maturational changes in pituitary and testicular function in the rat. $J$. Endocr. 80, 249-257.

Shaw, M.J., Georgopoulos, L.E. \& Payne, A.H. (1979) Synergistic effect of follicle-stimulating hormone and luteinizing hormone on testicular $3 \boldsymbol{\beta}$-hydroxysteroid dehydrogenase-isomerase: application of a new method for the separation of testicular compartments. Endocrinology 104, 912-918.

Received 13 November 1981 